\title{
In vitro propagation of Helianthemum almeriense Pau (Cistaceae)
}

\author{
MA Morte, M Honrubia * \\ Espinardo, Campus, Faculty of Biology, Plant Biology Department (Botany), 30071 Murcia, Spain
}

(COST Meeting, 21-23 May 1992, Dijon, France)

\begin{abstract}
Summary - Shoot tips and nodal segments were excised from seedlings grown in vitro. Outgrowth of axillary buds was achieved on Murashige and Skoog (MS) medium supplemented with $0.46 \mu \mathrm{M}$ kinetin without auxins. Cultures established from shoot tips and nodal segments had the same multiplication rate. Spontaneous rooting was observed at a low cytokinin concentration until the 6th subculture. After that, spontaneous rooting was negligible. The rooting percentage increased to $92 \%$ via macronutrient dilution. The rooted shoots were grown in a peat-sand-vermiculite mixture.
\end{abstract}

in vitro propagation / Helianthemum (Cistaceae)

Résumé - Propagation in vitro de Helianthemum almeriense Pau (Cistaceae). Des extrémités de tiges et des segments nodaux ont été excisés de semis cultivés in vitro. La croissance de bourgeons axillaires a été obtenue sur le milieu de Murashige et Skoog (MS) avec $0.46 \mathrm{mmol}^{-1}$ de kinétine sans auxine. Les cultures établies à partir d'extrémités de tiges ou de segments nodaux ont eu le même taux de multiplication. L'enracinement spontané a été observé à faible concentration de cytokinine jusqu'à la $6 e$ subculture. Ultérieurement, l'enracinement spontané est devenu négligeable. Le pourcentage d'enracinement a augmenté jusqu'à 92\% en diluant les macroéléments. Les tiges enracinées ont été cultivées sur un mélange de tourbe, sable, vermiculite.

propagation in vitro / Helianthemum (Cistaceae)

\section{INTRODUCTION}

Helianthemum almeriense Pau (Cistaceae) is one of the most abundant autochtonous shrubs of the semi-arid areas in Spain. This crop is of great interest for reafforestation. It establishes endomycorrhizae with Ascomycetes such as Terfezia and Picoa (desert truffles) (Honrubia et al, 1992) which are of marked gastronomic and economic importance in the area. In this paper, we have established a protocol for in vitro propagation of this crop.

\section{MATERIALS AND METHODS}

Mature $H$ almeriense seeds were surface-sterilized by pre-treatment for $10 \mathrm{~s}$ in a $70 \%$ ethanol solution, followed by treatment for $20-30 \mathrm{~min}$ in $10 \%$ commer- cial bleach ("Domestos") solution, followed by rinsing in $80 \%$ ethanol for $10 \mathrm{~s}$ and 3 times 5 -min rinses in sterile distilled water.

Basal medium consisted of Murashige and Skoog (1962) (MS) salts supplemented with myo-inositol (100 mg. $\left.\left.\right|^{-1}\right)$ thiamine- $\mathrm{HCl}\left(0.1 \mathrm{mg} . \mathrm{I}^{-1}\right)$, nicotinic acid $\left(0.5 \mathrm{mg} . \mathrm{I}^{-1}\right)$, pyridoxine- $\mathrm{HCl}\left(0.5 \mathrm{mg}^{-1}\right)$ and $3 \%$ sucrose. $\mathrm{pH}$ was adjusted to 5.8 before autoclaving. The medium was solidified with $7 \mathrm{~g} . \mathrm{I}^{-1}$ Panreac agar and autoclaved for $20 \mathrm{~min}$ at $121^{\circ} \mathrm{C}$ and $103 \mathrm{kPa}$. Naphthalene acetic acid (NAA) and 6benzylaminopurine (BAP) and kinetin were added as indicated.

Seeds were sown on hormone-free MS medium and germinated under a 16-h photoperiod at $25^{\circ} \mathrm{C}$. Shoot tips and nodal segments were excised from the seedlings and transferred to multiplication medium. Thirty cultures per treatment were grown at 25 $\pm 2{ }^{\circ} \mathrm{C}$ and $40 \mu \mathrm{mol} . \mathrm{m}^{-2} . \mathrm{s}^{-2}$ Growlux fluorescent light and a $16-\mathrm{h}$ photoperiod. Experiments were repeated at least 3 times.

\footnotetext{
* Correspondence and reprints
} 
Following shoot multiplication and elongation, 15$25 \mathrm{~mm}$ shoots were transferred to root induction medium consisting of MS medium salts at several strengths $(1 x, 1 / 2 x, 1 / 4 x)$ with or without activated

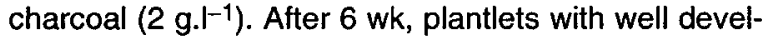
oped roots were potted in a peat-sand-vermiculite mixture $(6: 2: 2, v / v)$. The plantlets were adapted to growth chamber conditions $\left(25 \pm 2^{\circ} \mathrm{C}\right)$ with a 16-h photoperiod. They were gradually exposed to reduced relative humidity by progressively removing a plastic cover during a period of $2-3 \mathrm{wk}$. Once acclimatization was accomplished, the plants were transferred to the greenhouse.

\section{RESULTS}

After 2 wk in MS medium without growth regulators, most seeds $(75 \%)$ had germinated. Production of axillary shoots began after 2 wk when kinetin or BAP had been added. Cultures established from shoot tips $(1 \mathrm{~cm})$ and nodal segments $(0.5-1 \mathrm{~cm})$ had the same multiplication rate. The maximum number of microshoots per explant was obtained with 0.46 or $0.93 \mu \mathrm{M}$ kinetin (table I, fig 1). Progressively higher concentrations of BAP alone $(1.78,2.66,3.55$ $\mu \mathrm{M})$ or in combination with $0.27 \mu \mathrm{M}$ NAA $(0.44$,

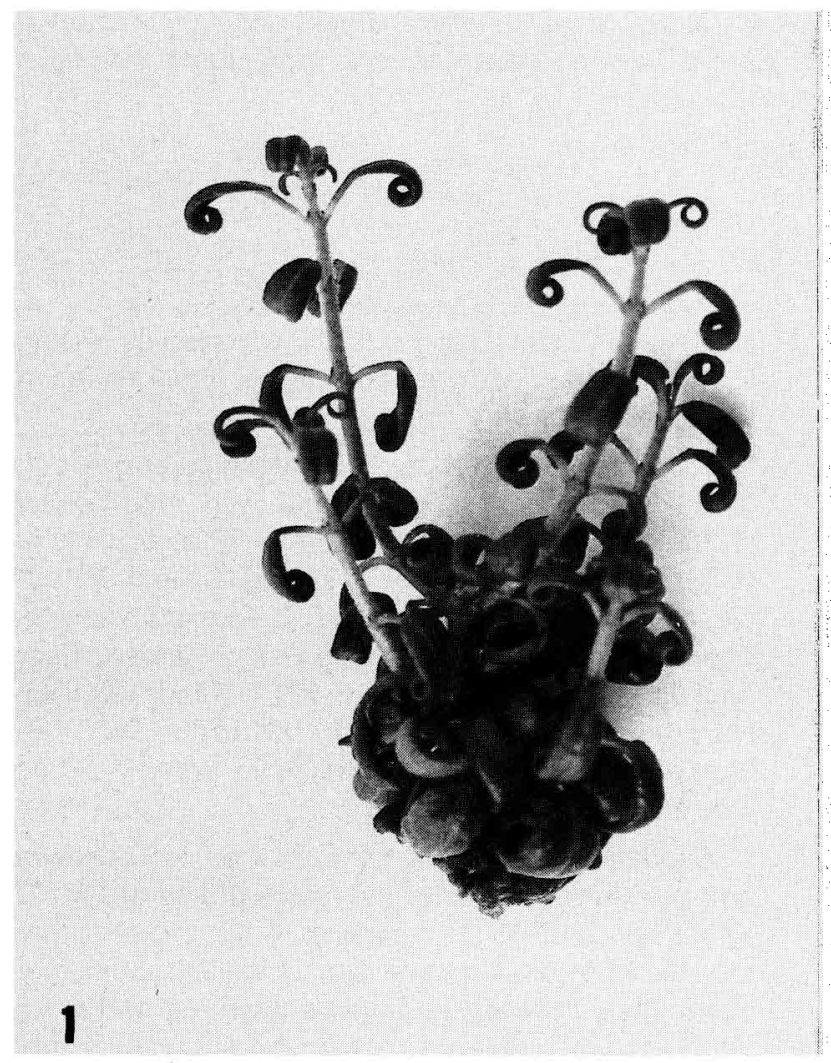

Fig 1. Shoots of Helianthemum almeriense proliferated on basal medium with $0.46 \mu \mathrm{M}$ of kinetin.
Table I. The influence of BA, kinetin and NAA on number of microshoots produced from shoot tips and nodal segments of $H$ almeriense cultured for $12 \mathrm{wk}$ in vitro (data based on 30 cultures/treatment).

MS medium
+ growth regulator $(\mu M)$$\quad \begin{gathered}\text { No of microshoots/ } \\ \text { explant }\end{gathered}$

$\begin{array}{llll}0.22 & 0.0 & 0.0 & 2.48^{\mathrm{abc}} \\ 0.44 & 0.0 & 0.0 & 2.73^{\mathrm{abc}} \\ 0.88 & 0.0 & 0.0 & 2.29^{\mathrm{abc}} \\ 1.33 & 0.0 & 0.0 & 2.79^{\mathrm{abc}} \\ 1.78 & 0.0 & 0.0 & 0.99^{\mathrm{a}} \\ 2.66 & 0.0 & 0.0 & 1.31^{\mathrm{ab}} \\ 3.55 & 0.0 & 0.0 & 1.66^{\mathrm{ab}} \\ 0.22 & 0.0 & 0.27 & 2.91^{\mathrm{bc}} \\ 0.44 & 0.0 & 0.27 & 2.33^{\mathrm{abc}} \\ 0.88 & 0.0 & 0.27 & 2.32^{\mathrm{abc}} \\ 1.33 & 0.0 & 0.27 & 1.86^{\mathrm{ab}} \\ 0.0 & 0.46 & 0.0 & 7.72^{\mathrm{d}} \\ 0.0 & 0.93 & 0.0 & 6.12^{\mathrm{d}} \\ 0.0 & 1.39 & 0.0 & 4.08^{\mathrm{c}}\end{array}$

Data in a column followed by the same letter are not significantly different $(P \leq 0.05)$ as determined by Duncan's test.

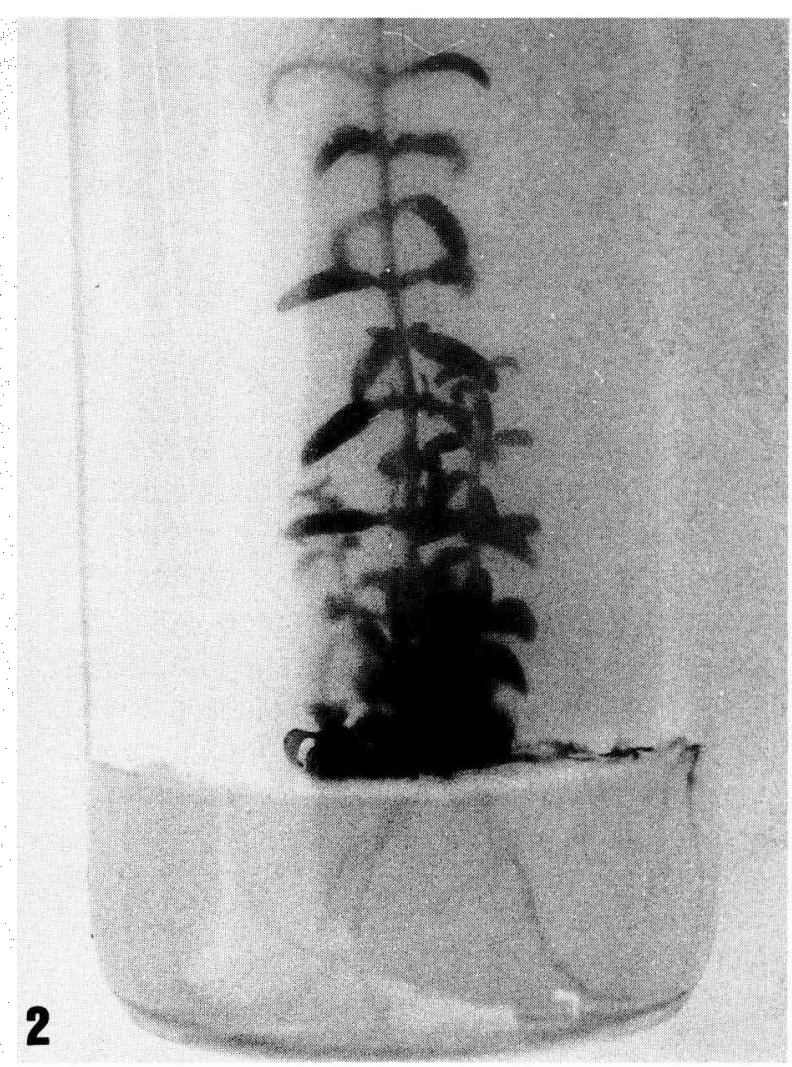

Fig 2. Formation of roots at the base of a Helianthemum almeriense plantlet. 
$0.88,1.33 \mu \mathrm{M}$ ) resulted in a decrease in the number of shoots. Callus was induced at $3.55 \mu \mathrm{M}$ BAP and $1.33 \mu \mathrm{M}$ BAP with $0.27 \mu \mathrm{M}$ NAA. A slight decrease in the propagation rate was observed after the 4th subculture (5.6 microshoots per explant).

Spontaneous rooting was observed at a low cytokinin level until the 6th subculture (fig 2). After that rooting was negligible. To avoid necrosis during rooting, it was necessary to select shoots between 15-25 mm long. Rooting percentage was enhanced to $92 \%$ by macronutrient dilution (fig 3). Addition of charcoal reduced rooting. Approximately $95 \%$ rooted plants transferred to soil survived. All these plants were first grown in the greenhouse and afterwards in the field. They showed normal development and flowering.

\section{DISCUSSION AND CONCLUSION}

The present report shows that in vitro methods are a feasible means to propagate and obtain true-to-type plants of Helianthemum almeriense. Of the 2 cytokinins tested, kinetin was more efficient than BAP. When used at a low concentration $(0.46 \mu \mathrm{M})$, it allowed good growth of the shoot which is particularly critical when shoot

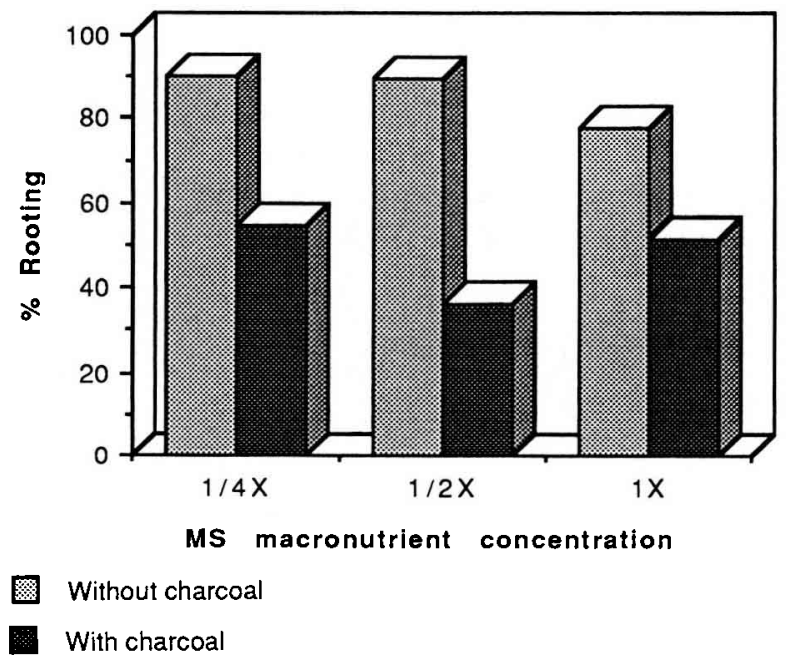

Fig 3. Influence of concentration of macronutrients and addition of charcoal on in vitro rooting in medium without growth regulators after 4 wk (48 explants per treatment). multiplication through axillary branching is carried out by taking nodal segments at each subculture. In this case the rate of shoot multiplication is directly related to the elongation of shoots and the number of nodal cuttings available at the end of each passage (Bhojwani and Razdan, 1983). This also allowed exclusion of an additional in vitro step of shoot elongation on a medium with low concentration of cytokinin before rooting.

Quoirin et al (1977) showed that dilution of macronutrients improved the rooting of several Prunus species. M'Kada et al (1990) observed the same in Cistus $x$ purpureus. We also observed an increase in rooting after dilution (fig 3). Contrary to Cheema and Sharma (1983) and M'Kada et al (1990), charcoal decreased root production. The effect of charcoal may be related to the adsortion of endogenous auxins which promote rooting.

The propagation of Helianthemum almeriense by tips and nodal microcuttings is a very efficient method. However, an economic study would have to be performed to determine whether this process is more advantageous than traditional seed propagation.

\section{REFERENCES}

Bhojwani SS, Razdan MK (1983) Plant Tissue Culture: Theory and Practice. Elsevier, Amsterdam

Cheema GS, Sharma DP (1983) In vitro propagation of apple rootstock. Acta Hortic 131, 75-88

Honrubia M, Cano A, Molina-Niñirola C (1992) Hypogenous fungi from Southern Spanish semi-arid lands. Persoonia 14(4), 647-653

M'Kada J, Dorion N, Bigot C (1991) In vitro propagaton of Cistus x purpureus. Lam Sci Hortic 46, 155160

Murashige T, Skoog F (1962) A revised medium for rapid growth and bioassays with tobacco tissue culture. Physiol Plant 15, 473-497

Quoirin M, Lepoivre P, Boxus P (1977) Un premier bilan de 10 années de recherches sur les cultures de méristèmes et la multiplication in vitro de fruitiers ligneux. CR Rech (1976-1977), Stat Cultures Fruitières Maraîchères, Gembloux. 93-117 